had a proportionately heavier bill.

I should note that September 13 is a very late date for this species, particularly at such a northerly latitude. These birds begin their migration southward in July, and are virtually absent from most of their breeding range by mid-August. ${ }^{3}$ Prothonotary Warblers breed from Minnesota to Texas and eastward. 1

There is only one previous record of this species for Regina and Saskatchewan, a male seen on 17
May, 1969, in the same area of the park, by D. G. Bobbit and Father H. B. Bedard.2

1BENT, A. C. 1953. Life histories of North American wood warblers. U.S. Nat. Mus. Bull. 203.

${ }^{2}$ BOBBIT, D. G. 1969. Sighting of a Prothonotary Warbler in Regina. Blue Jay 27(3):149.

3WALKINSHAW, L. H. 1957. Prothonotary Warbler. Pages 46-49 in The warblers of North America. Devin-Adair, New York.

\section{CASPIAN TERN NESTS AT LAST MOUNTAIN LAKE, SASKATCHEWAN}

J. R. CALDWELL and C. JORGENSON, Canadian Wildlife Service, Saskatoon, Saskatchewan.

On 21 July, 1978, we inspected Perry's Point (on the east shore of Last Mountain Lake, 10 miles west of Govan) and a small, sand and rock island just off its southern tip. Our objective was to find out whether pelicans and/or cormorants were nesting there since both species are seen on the lake each summer and have nested on Perry's Point in the past. We found no evidence that these species were breeding at either location but did see eggs and young of Common Terns and two Piping Plover chicks on the small island. A large gull colony occupied the tip of Perry's Point.

While on the little island our attention was attracted by two large terns that kept diving at us. These birds had large, red bills, which is a distinguishing characteristic of the Caspian Tern according to Peterson's Field Guide to Western Birds. By their aggressive behaviour we felt certain that they were nesting. On 24 July, Brian Johns and Bob Godwin (Canadian Wildlife Service, Saskatoon) were able to verify that Caspian Terns were breeding at Last Mountain Lake when they observed the adults offering food to a chick on the small island adjacent to Perry's Point. This breeding record brings to two (the other is Doré Lake) the number of places in Saskatchewan where Caspian Terns have been found nesting. ${ }^{1}$ It extends the list of birds recorded at the north end of Last Mountain Lake to 218 and the number of breeding species to 91 .

We thank Dr. J. B. Gollop (Canadian Wildlife Service, Saskatoon) for his interest in our sighting of Caspian Terns at Last Mountain Lake that led to verifying the nesting record.

1HOUSTON, STUART. 1956. The Caspian

Tern in Saskatchewan - with first breeding record. Blue Jay 14:116-117. 